\title{
In Vitro and In Situ Degradation Characteristics and Rumen Fermentation Products of Moringa oleifera Harvested at Three Different Ages
}

\author{
A.R. Seradj ${ }^{a}$, H. Morazán ${ }^{b}$, M. Fondevilac ${ }^{c}$ J.B. Liang ${ }^{d}$, G. de la Fuente ${ }^{a}$, \& J. Balcellsa,* \\ aDepartamento de Ciencia Animal, Universidad de Lleida, ETSEA, \\ Alcalde Rovira Roure 191, 25198, Lleida, Spain \\ bDepartamento Académico de Investigación y Extensión Agrícola, Universidad Nacional de Agricultura, \\ Barrio el Espino, Catacamas Olancho, Honduras \\ ‘Departamento de Producción Animal y Ciencia de los Alimentos, Instituto Agroalimentario de Aragón (IA2), \\ Universidad de Zaragoza-CITA, \\ Miguel Servet 177, 50013 Zaragoza, Spain \\ dnstitute of Tropical Agriculture and Food Security, Universiti Putra Malaysia, \\ 43400 UPM Serdang, Malaysia \\ *Corresponding author: balcells@ca.udl.cat \\ (Received 09-10-2018; Revised 16-12-2018; Accepted 17-01-2019)
}

\begin{abstract}
Besides the beneficial agronomic properties such as drought tolerance and high biomass production, the high crude protein content of Moringa oleifera (Moringa) makes it comparable to the other high quality forages. This study aimed to evaluate whether Moringa can be an appropriate substitute for alfalfa as a ruminant feed. The study consisted of 4 treatments, namely Moringa leaves harvested at 30 (M30), 40 (M40), and 50 (M50) days after pruning, and alfalfa (Medicago sativa) hay as a control. Simultaneously, their organic matter digestibilities and fermentation characteristics were analyzed by in vitro gas production technique and rumen dry matter and protein degradability kinetics were analyzed by using the nylon bags (in situ) procedure. The results of in vitro study revealed that the potential cumulative gas production for Moringa sample harvested at 30 days after pruning was higher than that of alfalfa while the rate of gas production and the concentrations of ammonia and volatile fatty acids (VFA) in Moringa were similar to alfalfa. Moringa harvested at different times had higher in vitro organic matter digestibility (IVOMD) and metabolizable energy (ME) content as compared with alfalfa. Despite the apparent higher soluble fraction (a) and the fractional degradation rate (c) in the Moringa samples of various ages than those for alfalfa, the differences were not significant. However, in situ potentially degradable fraction (b) for DM and CP of Moringa harvested at different ages were higher than those of alfalfa $(\mathbf{P}<0.05)$. The in vitro fermentation and in situ degradation parameters suggested high similarities in the kinetics of gas production (i.e. $a, b$, and c) and DM degradation pattern among the three different cutting ages of Moringa and nutritionally they were comparable to alfalfa. In conclusion, alfalfa could be replaced with Moringa leaves in diet of ruminant animal without any adverse effect.
\end{abstract}

Keywords: ewes; fermentation parameters; in vitro gas production; in situ degradation technique; moringa oleifera

\section{INTRODUCTION}

The limited access to feed sources is the major constraint for ruminant production in the tropical and sub-tropical areas, especially during the dry season when protein content and dry matter (DM) digestibility of the tropical pastures reach the minimum levels (Melesse et al., 2013). In such conditions, foliage from the local drought tolerant species such as Moringa (Moringa oleifera) would be an appropriate alternative to be cultivated because of its drought tolerance, high biomass yield (Odee, 1998), and high content of digestible crude protein in the fresh leaves. More recently, Fitri et al. (2015) reported that leaves and stem of Moringa could be used as a feed additive to prevent oxidative stress in animals. However, the presence of some anti-nutritional factors such as oxalates $(41 \mathrm{~g} / \mathrm{kg})$, saponins $(12 \mathrm{~g} / \mathrm{kg})$, and phytates $(31 \mathrm{~g} / \mathrm{kg})(G u p t a$ et al., 1989) may compromise its utilization as a forage source. It is also true that such anti-nutritional factors are water-soluble and can be removed by soaking and boiling in water (Adeleke $e t$ al., 2017) or easily extracted in aqueous ethanol (Gupta et al., 1989). The utilization of such forage material as a source of fresh forage in ruminant species thus depends on the balance between the adequacy of nutrient composition and the deleterious effect of the anti-nutritive factors in the fresh material.

The presence of anti-nutritional compounds in a forage can adversely affect its consumption by animals and often cannot be fed as a single feed to evaluate its quality. To overcome the above problem, in vitro and in situ approaches are useful low cost tools to determine 
forage digestive value and utilization (Pashaei et al., 2010). Since maturity stage is known to influence the nutritional value of forages (Müller, 2011), information on different harvesting ages on nutritive value of Moringa is scanty. Foliage protein from Moringa trees at three maturity stages were compared against alfalfa, a wellaccepted roughage-feed as a control. Simultaneously, their organic matter digestibilities and fermentation characteristics by in vitro gas production technique and rumen dry matter and protein degradability kinetics using the nylon bags procedure were determined with the overall objective to evaluate whether Moringa can be an appropriate substitute for alfalfa as a ruminant feed.

\section{MATERIALS AND METHODS}

\section{Substrates}

Moringa forage consisting of leaves, twigs, and new buds were harvested from an experimental plot located in the Finca Agroecológica Nacional, University of Agriculture located in Catacamas, Honduras. The region is at $350 \mathrm{~m}$ altitude, and has an average temperature of $25^{\circ} \mathrm{C}$, relative humidity of $74 \%$, and an average annual rainfall of $1300 \mathrm{~mm}$. Twenty trees were randomly selected for each sampling time, pooled to obtain $1 \mathrm{~kg}$ fresh material, dried ( $50^{\circ} \mathrm{C}$ for $48 \mathrm{~h}$ ), ground to pass through a $1 \mathrm{~mm}$ screen, and stored in sealed cans at $7^{\circ} \mathrm{C}$ until use.

The study consisted of 4 treatments, namely Moringa leaves harvested at 30 (M30), 40 (M40), and 50 (M50) days after pruning, and alfalfa (Medicago sativa) hay as a control. Alfalfa was obtained from the commonly practiced second harvest (middle May) and were dried and treated in a similar way as the Moringa samples.

\section{In Situ Trial}

The trial was carried out at the Servicio de Experimentación Animal, University of Zaragoza, Spain, according to the Ethic Committee for Animal Experimentation of the University of Zaragoza. The care and use of animals were performed in agreement with the Spanish Policy for Animal Protection RD 53/2013 that complies with EU Directive 2010/63 on the protection of animals used for experimental and other scientific purposes. For determining in situ rumen degradability, approximately $2.5 \mathrm{~g}$ DM of each sample was weighed into $16.5 \times 10 \mathrm{~cm}$ Dacron bags with $45-\mu \mathrm{m}$ pore size. Immediately before the morning feeding (0830), 5 bags per treatment were introduced into the rumen of each of the 4 adult, rumen cannulated Rasa Aragonesa ewes (71.2 $\pm 4.9 \mathrm{~kg}$ weight), which were housed in individual pens in a controlled environment $\left(19\right.$ to $\left.22^{\circ} \mathrm{C}\right)$ and received alfalfa (ad libitum) plus $0.25 \mathrm{~kg}$ of a concentrate supplement ( 0.60 barley, 0.20 corn, and 0.20 soybean meal) daily. The bags were incubated in the rumen for $4,8,12,24$, and $48 \mathrm{~h}$, then removed and hand-washed with cold tap water until the water remained clear. An additional bag from each treatment was directly washed with cold tap water to estimate zero time washouts. The bags were then dried in an oven at $60^{\circ} \mathrm{C}$ for $48 \mathrm{~h}$ for determination of DM disappearance.

\section{In Vitro Trial}

The trial was conducted in the Laboratory of Nutrition, the University of Lleida, Spain. Three in vitro incubation runs were carried out in three consecutive weeks. The rumen inoculum was harvested from the same ewes used in the in situ experiment by taking rumen aliquots of the four ewes at $0800 \mathrm{~h}$, pooled and transported to the laboratory in a pre-heated $\left(39^{\circ} \mathrm{C}\right)$ thermos flask. The rumen inoculum was filtered through a double-layer gauze and used as inoculum at 0.10 of total incubation volume. Five serum glass bottles (with $120 \mathrm{~mL}$ total volume) with $600 \mathrm{mg}$ DM of each substrate were filled with $80 \mathrm{~mL}$ of incubation solution including rumen inoculum and mineral, buffer, and reducing solutions, but without resazurin and micromineral solutions. All incubations were prepared under a $\mathrm{CO}_{2}$ stream (Seradj et al., 2014). Once filled, the bottles were sealed with butyl rubber stoppers and aluminum crimps and incubated at $39 \pm 1^{\circ} \mathrm{C}$ in a shaking water bath for $48 \mathrm{~h}$. For each incubation run, five bottles without substrate were also included as blanks (BLK).

Pressure measurements were determined with a HD2124 Manometer provided with a TP704 pressure gauge (DELTA OHM, Italy) at 2, 4, 6, 8, 10, 12, 18, 24, and $48 \mathrm{~h}$ of incubation. The pressure readings were converted into volumes by a linear regression established between the pressure and known air volumes at an equal incubation temperature. Gas volume at each incubation time was expressed per unit of DM. A sample from the incubation solution was taken at the onset of each incubating set (Time 0) for analyses. Besides, two bottles per treatment were opened after $24 \mathrm{~h}$ gas measurement and the content was filtered through a $1 \mathrm{~mm}$ pore size metal sieve and sampled for ammonia nitrogen $(2 \mathrm{~mL}$ over $0.8 \mathrm{~mL}$ of $0.5 \mathrm{NHCl})$ and volatile fatty acids (VFA, $4 \mathrm{~mL}$ on $1 \mathrm{~mL}$ solution made up with 20 $\mathrm{mL} / \mathrm{L}$ ortho-phosphoric acid and $2 \mathrm{~g} / \mathrm{L}$ of 4 -methylvaleric acid, in distilled water) concentrations. The samples were immediately frozen $\left(-20^{\circ} \mathrm{C}\right)$ until further analyses. The remaining bottles for each treatment were kept incubated for gas production measurements up to $48 \mathrm{~h}$.

\section{Chemical Analyses}

The substrates were analyzed in duplicate following the procedures of AOAC (2010). The dry matter (DM), crude ash (CA), crude protein (CP), and ether extract (EE) contents together with the proportion of neutral detergent fiber (NDF), acid detergent fiber (ADF), and lignin (ADL) were determined following the procedures and reference number previously described (Seradj et al., 2018a). The proportion of non-fibrous carbohydrates (NFC) was calculated as:

$\mathrm{NFC}=100-(\mathrm{CP}+\mathrm{NDF}+\mathrm{EE}+\mathrm{ash})$

Determination of Ammonia-N and molar VFA profile were described in our previous study (Seradj 
et al., 2018b). In brief, ammonia-N concentration was determined after sample centrifugation (25,000 $\mathrm{g}$ for 20 min). The VFA concentration and the molar VFA profile were determined by Agilent gas chromatograph (7890A, Net Work GC System, Beijing Elmer, Boston, USA), using a capillary column (BP21, $30 \mathrm{~m} \times 0.25 \mathrm{~mm}$ ID $\times 0.25$ $\mu \mathrm{m}$, SGE, Australia) equipped with a flame ionization detector (FID). The gas chromatograph was operating at $150^{\circ} \mathrm{C}$ at the injector, and $250^{\circ} \mathrm{C}$ at the detector and variable temperatures in oven $\left(0.2 \mathrm{~min}\right.$ at $150^{\circ} \mathrm{C}$ and $0.2 \mathrm{~min}$ at $165^{\circ} \mathrm{C}\left[3^{\circ} \mathrm{C} / \mathrm{min}\right]$, and $10 \mathrm{~min}$ at $230^{\circ} \mathrm{C}\left[25^{\circ} \mathrm{C} /\right.$ min]). The carrier gas was helium (99.99\% purity [C50], Carburos Metalicos, Spain) and the total injection time was $18 \mathrm{~min}$.

\section{Calculations and Statistical Analyses}

Rumen degradation kinetics of DM and $\mathrm{N}$ (only for alfalfa and M40 cut) were determined by fitting the in situ results to the exponential model proposed by Ørskov \& McDonald (1979):

$$
\mathrm{p}=\mathrm{a}+\mathrm{b}\left(1-\mathrm{e}^{-\mathrm{ct}}\right) \text {, }
$$

in which $\mathrm{p}$ is the amount degraded at the time, a is the soluble or immediately degraded fraction, $b$ is the potentially degradable insoluble fraction, and $\mathrm{c}$ is the fractional degradation rate constant. Effective degradability of dry matter (EDDM) and crude protein (EDCP) were calculated (Ørskov \& McDonald, 1979), assuming an outflow rate $(\mathrm{k})$ of 0.02 and 0.05 per hour, representing maintenance and production, respectively, as follows:

$$
\mathrm{ED}=\mathrm{a}+\mathrm{b} \times \mathrm{c} /(\mathrm{c}+\mathrm{k}) \text {, }
$$

To determine the in vitro gas production kinetics, recorded volumes of gas production were fitted iteratively (SAS NLIN program) to the Gompertz model (Tjørve \& Tjørve, 2017):

$$
\mathrm{y}=\operatorname{aexp}\left(-\exp ^{\text {-bexp(t-c) }}\right)
$$

where $\mathrm{y}$ is the cumulative gas production at a given time (mL); a is the potential cumulative gas production $(\mathrm{mL}) ; \mathrm{b}$ is the rate of gas production $(\mathrm{mL} / \mathrm{h}) ; \mathrm{t}$ is the time of fermentation (h); and $\mathrm{c}$ is the discrete lag time $(\mathrm{h})$.

In vitro OM digestibility (IVOMD) and metabolizable energy (ME; MJ/kg DM) were estimated using the following equations (initially proposed by Menke \& Steingass) cited in Ülger et al. (2018):

$\mathrm{IVOMD}=14.88+0.889 \mathrm{GP}+0.45 \mathrm{CP}+0.0651$ ash

$\mathrm{ME}(\mathrm{MJ} / \mathrm{kg} \mathrm{DM})=2.20+0.136 \mathrm{GP}+0.057 \mathrm{CP}+$ $0.0029 \mathrm{EE}^{2}$

where GP is the volume of gas produced (mL/200 $\mathrm{mg}$ DM substrate) after $24 \mathrm{~h}$ of incubation.

For the statistical analysis of results from the in situ trial, a randomized complete block assay was designed considering the 4 rumen cannulated sheep $(n=4)$ with 4 treatment factors (A, M30, M40, and M50). The components of degradation $(a, b, c$, and ED at 0.02 and 0.05$)$ were analyzed using a general linear model of SAS (Inst. Inc., Cary, NC) where the model of analysis for DM degradation components included animal (considered as the experimental unit) and treatment (A, M30, M40, and M50) as fixed factors and for the CP degradation components the model composed of animal and treatment (A and M40).

In the in vitro trial, 3 incubation series were separately conducted using a completely randomized block design with 4 treatment factors (A, M30, M40, and M50) occurred in 3 different blocks (incubation series). Each incubation set was considered as an experimental unit $(n=3)$. The mixed model was performed for most of the variables with repeated measurements throughout the incubation period i.e., gas production results. The model included block (considered as a random effect), treatment, time of incubation (considered as repeated measures) and their possible interactions as fixed factors. The general linear model (GLM) was applied (using the same statistical package) in the case of the gas production components $(\mathrm{a}, \mathrm{b}$, and $\mathrm{c})$, VFA, and ammonia concentrations. The model included block and treatment as fixed factors.

In both trials (in situ and in vitro), the Tukey multiple comparison procedure was applied to all treatments and significant differences and tendencies were declared at $\mathrm{P}<0.05$ and $\mathrm{P}<0.10$, respectively.

\section{RESULTS}

Chemical composition of the alfalfa and the three Moringa samples are shown in Table 1. Alfalfa had lower EE content than all the 3 cuts of Moringa, and EE of the latter decreased with cutting age $(30>40>50$ days after pruning). All the three Moringa samples had lower proportions of ash, NDF, ADF, and ADL but higher NFC as compared to alfalfa. No significant differences were detected in the CP composition among samples.

The DM degradation kinetics data are presented in Table 2. Soluble fraction (a) and fractional degradation rate (c) did not differ among substrates ( $P>0.10)$, however, the insoluble but potentially fermentable fraction (b) was higher in Moringa than alfalfa $(\mathrm{P}<0.01)$ and with no differences among the three Moringa samples were noted. Consequently, the effective degradability of dry

\begin{tabular}{|c|c|c|c|c|}
\hline & \multicolumn{4}{|c|}{ Substrates } \\
\hline & Alfalfa & M30 & M40 & M50 \\
\hline Dry matter, \% & 23.2 & 25.6 & 25.7 & 26.1 \\
\hline Ether extract, \% DM & 2.3 & 4.3 & 5.3 & 5.2 \\
\hline Crude protein, \% DM & 21.7 & 20.1 & 21 & 20.4 \\
\hline Ash, \% DM & 9.7 & 8.7 & 9.2 & 9.0 \\
\hline $\begin{array}{l}\text { Neutral detergent fiber, } \\
\% \mathrm{DM}\end{array}$ & 28.5 & 20.0 & 17.7 & 19.3 \\
\hline $\begin{array}{l}\text { Acid detergent fiber, \% } \\
\text { DM }\end{array}$ & 19.8 & 9.8 & 8.7 & 8.8 \\
\hline $\begin{array}{l}\text { Acid detergent lignin, } \\
\% \mathrm{DM}\end{array}$ & 4.2 & 1.7 & 1.6 & 1.3 \\
\hline $\begin{array}{l}\text { Non-fibrous } \\
\text { carbohydrates, \% DM }\end{array}$ & 39.0 & 47.2 & 47.0 & 46.1 \\
\hline
\end{tabular}
matter content (EDDM), at the theoretical outflow rates

Table 1. Chemical composition of the experimental substrates

Note: Moringa leaves harvested at 30 (M30), 40 (M40), and 50 (M50) days after pruning. $\% \mathrm{DM}=$ percentage of dry matter. 
at maintenance or two-fold maintenance $[\mathrm{k}=0.02$ and 0.05] were higher $(\mathrm{P}<0.01)$ for the Moringa than the alfalfa substrates but not among the Moringa samples.

Since no differences were observed in the DM degradability among the three Moringa samples (Table 2), M40 sample was used as a representative of Maringa to compare with alfalfa for $\mathrm{CP}$ degradation. The results were rather similar to those obtained for the DM degradation kinetics that Moringa samples had a higher $(\mathrm{P}=$ $0.05)$ proportion of insoluble but potentially degradable $\mathrm{CP}$ fraction (b), but such differences were only reflected in a marginally higher EDCP of M40 at $\mathrm{k}=0.02(\mathrm{P}=0.07)$.

Gas production up to $48 \mathrm{~h}$ incubation and its related parameters together with the metabolizable energy (ME) concentration and organic matter digestibility (IVOMD) are presented in Figure 1 and Table 3. It is worthwhile to mention that the fitting of gas production volumes to the curves always rendered $\mathrm{R}$ values over 0.99 . From 4 to $24 \mathrm{~h}$ incubation, the volume of gas produced by M30 and M40 were higher than that of alfalfa $(\mathrm{P}<0.01)$ whereas M50 sample recorded intermediate values $(\mathrm{P}>0.05)$; however, the differences between gas produced by M50 and alfalfa only reached statistical significance between 6 to $8 \mathrm{~h}$ post incubation $(\mathrm{P}<0.05)$. No statistical differences were detected among the treatments at $48 \mathrm{~h}$ after onset on the fermentation process $(\mathrm{P}>0.05)$. The potential cumulative gas production (a) recorded for M30 Moringa was higher than that of alfalfa $(P=0.04)$, although the differences were not detected among the different Moringa nor between alfalfa and M40 and M50 samples (Table 3). The lag time (c) was smaller in M40 than in alfalfa $(\mathrm{P}<0.04)$, without any difference among the rest of substrates. Accordingly, the IVOMD of M30 and M40 was higher than that of alfalfa $(\mathrm{P}=0.01)$ with no difference between M50 and the other substrates. All Moringa samples showed higher ME

Table 2. Dry matter degradation kinetics of alfalfa and different cuts of Moringa oleifera collected at 30 (M30), 40 (M40), and 50 (M50) days after pruning, along with crude protein degradation kinetics of alfalfa and M40

\begin{tabular}{|c|c|c|c|c|c|c|}
\hline \multirow{2}{*}{ Coefficients } & \multicolumn{4}{|c|}{ Treatments } & \multirow{2}{*}{ SEM } & \multirow{2}{*}{ P-value } \\
\hline & Alfalfa & M30 & M40 & M50 & & \\
\hline \multicolumn{7}{|l|}{ Dry matter } \\
\hline $\mathrm{a}(\mathrm{g} / \mathrm{kg})$ & 164 & 275 & 268 & 263 & 32.7 & 0.12 \\
\hline $\mathrm{b}(\mathrm{g} / \mathrm{kg})$ & $476^{\mathrm{b}}$ & $636^{a}$ & $655^{a}$ & $668^{a}$ & 30 & $<0.01$ \\
\hline $\mathrm{c}\left(\mathrm{h}^{-1}\right)$ & 0.11 & 0.12 & 0.12 & 0.10 & 0.026 & 0.91 \\
\hline $\mathrm{ED}(\mathrm{k}=0.02)$ & $553^{b}$ & $816^{a}$ & 829 a & $805^{a}$ & 10.9 & $<0.01$ \\
\hline $\mathrm{ED}(\mathrm{k}=0.05)$ & $473^{b}$ & $719^{a}$ & $731^{a}$ & 689 a & 20.9 & $<0.01$ \\
\hline \multicolumn{7}{|l|}{ Protein } \\
\hline $\mathrm{a}(\mathrm{g} / \mathrm{kg})$ & 375 & --- & 347 & --- & 24.5 & 0.47 \\
\hline $\mathrm{b}(\mathrm{g} / \mathrm{kg})$ & $518 \mathrm{~b}$ & --- & $609 a$ & --- & 19.9 & 0.05 \\
\hline $\mathrm{c}\left(\mathrm{h}^{-1}\right)$ & 0.12 & --- & 0.14 & --- & 0.036 & 0.75 \\
\hline $\mathrm{ED}(\mathrm{k}=0.02)$ & 809 & --- & 871 & --- & 16.1 & 0.07 \\
\hline $\mathrm{ED}(\mathrm{k}=0.05)$ & 727 & --- & 783 & --- & 25.8 & 0.22 \\
\hline
\end{tabular}

Note: Means in the same row with different superscripts differ significantly $(\mathrm{P}<0.05)$. SEM $=$ standard error of means.

$\mathrm{a}$ is the soluble fraction $(\mathrm{g} / \mathrm{kg}$; fraction washed out at $\mathrm{t}=0$; this value resulted from the incubation of $0 \mathrm{~h}$ bags and fixed into the model); $\mathrm{b}$ is the insoluble degradable fraction $(\mathrm{g} / \mathrm{kg}), \mathrm{c}$ is the fractional degradation rate $(\mathrm{h}-\mathrm{l})$ and $\mathrm{t}$ is the time $(\mathrm{h})$.

$\mathrm{ED}=$ effective degradability.

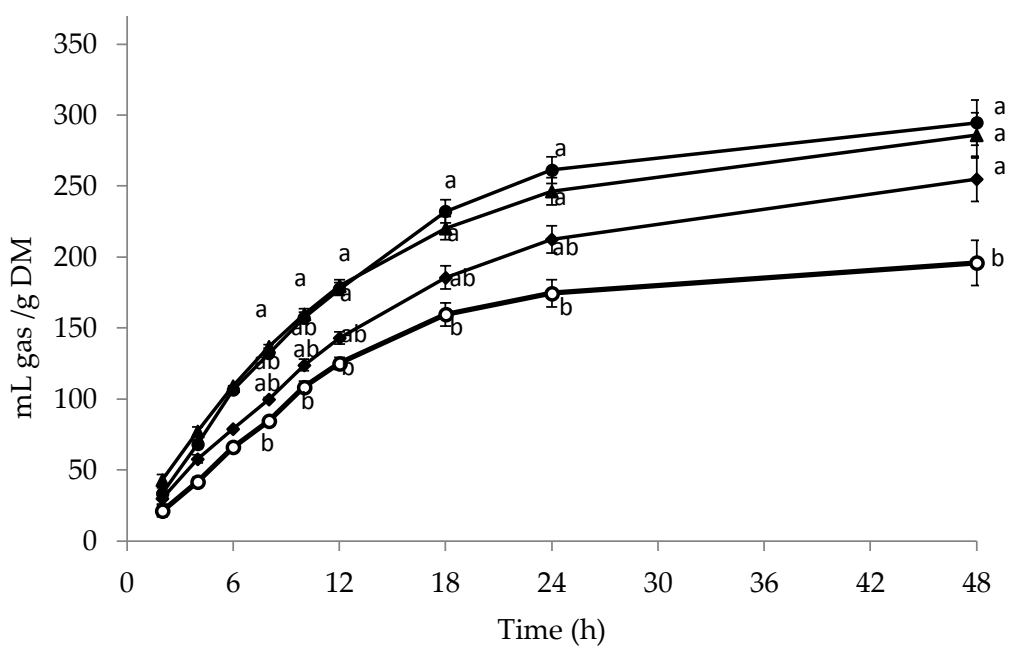

Figure 1. The in vitro gas production pattern (mL/g DM) of different cuts of Moringa oleifera collected at 30 (M30, $\bullet$ ), 40 (M40, $\mathbf{\Delta})$, and $50(\mathrm{M} 50, \bullet)$ days after pruning, and alfalfa $(\mathrm{o})$, along the incubation period. Different superscript letters $(\mathrm{a}, \mathrm{b})$ within each time point denote differences in gas production $(\mathrm{mL} / \mathrm{gDM})$. 
contents than that of alfalfa $(\mathrm{P}<0.01)$, but no significant difference among the Moringa samples.

After $24 \mathrm{~h}$ incubation, no difference $(\mathrm{P}>0.10)$ was observed in in vitro fermentation parameters such as ammonia-N concentrations and total concentrations or molar proportions of the different VFA between alfalfa and Moringa from three different cutting times (Table 4).

\section{DISCUSSION}

The nutritive values of the Moringa forage at three stages of maturity (30, 40, and 50 days after pruning) were evaluated and compared against alfalfa, which is considered as a high-quality forage due to its well-balanced nutritional composition and conventionally used as a standard forage for ruminants. The results of this study, besides comparing the nutrient compositions, also take account of the presence of secondary compounds such as oxalates, saponins, and phytates which have been previously reported in Moringa (Gupta et al., 1989) which may affect the potential value of Moringa as animal feed. On the other hand, Fitri et al. (2015) documented that the presence of secondary phenolic metabolites such as ferulic acid, chlorogenic acid, rutin, quecertin, caffeic acid in Moringa oleifera extracts (leaves and stems) provided strong scavenging free radicals and lipid peroxidation inhibition properties. Also, Astuti et al. (2012) showed that supplementation of 30\% Moringa Oleifera could optimize rumen fermentation and maintaining health status of local sheep.
The proportions of NDF and ADF in Moringa samples at different cutting times were lower than those reported by Astuti et al. (2012), presumably due to sampling procedures or agro-climatic conditions and age of the plants. It is rather bias to directly compare the alfalfa hay (a common second cutting in mid May) and Moringa cutting samples (harvested at 30, 40, and 50 days after pruning) on similar vegetative stage, but it is interesting to note that the fiber fraction of the Moringa was lower than that of alfalfa, indicating a higher content of non-fibrous carbohydrates which may suggest a higher digestibility and energy content for Moringa. The CP content was slightly lower than that of alfalfa but was within the range (227 to $178 \mathrm{~g} / \mathrm{kg}$ ) previously reported for Moringa foliage in studies of Astuti et al. (2012) and Sánchez et al. (2006).

The concentration of EE in the Moringa substrates was close to the value $(51 \mathrm{~g} / \mathrm{kg} \mathrm{DM})$ reported by Astuti et al. (2012) and slightly lower than 65 and $69 \mathrm{~g} / \mathrm{kg}$ DM observed in the other studies (Melesse et al., 2013; Dey et al., 2014). The result of our study showed that EE content increased from $43 \mathrm{~g} / \mathrm{kg}$ in M30 to $52 \mathrm{~g} / \mathrm{kg}$ in the M50 sample, presumably because seeds started to form in the more mature sample. The EE content of Moringa was within the average values for the conventional foliage which would not cause any potential reduction in rumen microbial fermentation as also mentioned in the study of Astuti et al. (2012).

The values of rumen solubility [coefficient (a) of the in situ trial] obtained for the Moringa foliage were

Table 3. Gas production coefficients together with estimated metabolizable energy (ME; MJ/kg DM) and in vitro organic matter digestibility (IVOMD; g/kg DM) of alfalfa and different cuts of Moringa oleifera collected at 30 (M30),40 (M40), and 50 (M50) days after pruning

\begin{tabular}{|c|c|c|c|c|c|c|}
\hline \multirow{2}{*}{ Variables } & \multicolumn{4}{|c|}{ Treatments } & \multirow{2}{*}{ SEM } & \multirow{2}{*}{ P-value } \\
\hline & Alfalfa & M30 & M40 & M50 & & \\
\hline a $(\mathrm{mL})$ & $203^{b}$ & $306^{a}$ & $294 \mathrm{ab}$ & $274^{a b}$ & 20.4 & 0.04 \\
\hline $\mathrm{b}(\mathrm{mL} / \mathrm{h})$ & 0.09 & 0.08 & 0.08 & 0.07 & 0.011 & 0.62 \\
\hline $\mathrm{c}\left(\mathrm{h}^{-1}\right)$ & $1.1^{\mathrm{a}}$ & $0.7^{a b}$ & $0.0^{b}$ & $0.4^{\mathrm{ab}}$ & 0.21 & 0.04 \\
\hline IVOMD & $620^{\mathrm{b}}$ & $760^{a}$ & $741^{a}$ & $677 \mathrm{ab}$ & 21.5 & 0.01 \\
\hline $\mathrm{ME}$ & $8.33^{b}$ & $10.97^{a}$ & 10.89 a & $9.92^{a}$ & 0.329 & $<0.01$ \\
\hline
\end{tabular}

Note: Means in the same row with different superscripts differ significantly $(\mathrm{P}<0.05)$. SEM= standard error of means; a= potential cumulative gas production $(\mathrm{mL}) ; \mathrm{b}=$ rate of gas production $(\mathrm{mL} / \mathrm{h}) ; \mathrm{c}=$ discrete lag time $(\mathrm{h})$.

Table 4. Average in vitro concentration of ammonia-N (mg/L), total volatile fatty acids concentration (VFA, mM), and molar VFA proportions of alfalfa and different cuts of Moringa oleifera collected at 30 (M30), 40 (M40), and 50 (M50) days after pruning

\begin{tabular}{|c|c|c|c|c|c|c|}
\hline \multirow{2}{*}{ Variables } & \multicolumn{4}{|c|}{ Treatments } & \multirow{2}{*}{ SEM } & \multirow{2}{*}{$\mathrm{P}$-values } \\
\hline & Alfalfa & M30 & M40 & M50 & & \\
\hline Ammonia-N & 307 & 269 & 292 & 295 & 11 & 0.20 \\
\hline Total VFA, mM & 40.0 & 41.9 & 42.8 & 38.2 & 1.74 & 0.33 \\
\hline \multicolumn{7}{|l|}{$\mathrm{VFA}, \mathrm{mol} / \mathrm{mol}$} \\
\hline Acetate & 0.65 & 0.64 & 0.63 & 0.64 & 0.006 & 0.16 \\
\hline Propionate & 0.22 & 0.23 & 0.23 & 0.21 & 0.005 & 0.13 \\
\hline Isobutyrate & 0.01 & 0.01 & 0.01 & 0.01 & 0.002 & 0.33 \\
\hline Butyrate & 0.09 & 0.09 & 0.10 & 0.10 & 0.003 & 0.37 \\
\hline Isovalerate & 0.02 & 0.02 & 0.02 & 0.02 & 0.001 & 0.33 \\
\hline Valerate & 0.01 & 0.01 & 0.01 & 0.01 & 0.001 & 0.29 \\
\hline
\end{tabular}

Note: $S E M=$ standard error of means 
numerically higher but not significant $(\mathrm{P}=0.12)$ as compared to alfalfa. On the average, the potential rumen degradability of the insoluble fraction (b) was about $28 \%$ higher in Moringa than that of alfalfa $(\mathrm{P}<0.01)$, which implied higher effective rumen DM degradabilities estimated at both outflow rates. The above data show that, like alfalfa, Moringa foliage is suitable to be used by rumen microorganism in spite of the presence of anti-nutritive factors in the latter. In agreement with the in situ potential DM degradability, cumulative gas production (a), as an index of substrate fermentation, was numerically higher in Moringa foliage than alfalfa but reached a statistical significance only with the M30 sample (Table 3). Moringa foliage was more fermentable since the fermentation process initiated earlier, as the lag time (c) was lower in the Moringa foliage, particularly in the M40 sample as compared to the alfalfa.

Differences recorded in the fermentation traits among substrates were due to their chemical compositions. The low fiber contents (NDF, ADF, and lignin) and the high proportion of non-structural carbohydrates in Moringa foliage contributed to their higher and faster degradations. Moreover, the variation in fibrous and non-fibrous carbohydrate contents due to the different maturity stages of the foliage may also account for the different in vitro degradation parameters with a negative correlation between DM degradability and NDF and ADF contents (Kulivand \& Kafilzadeh, 2015).

Estimations of ME and IVOMD (Table 3) from gas production kinetics are adequate for ration formulation and provide an economic value to non-conventional feedstuffs. In our study, the comparison among treatments (different cuts of Moringa and alfalfa) were more pronounced in ME content than in kinetics of gas production (i.e. a, b, and c), and such finding could be expected due to the higher EE content in Moringa foliage, which contributed significantly in the estimation of ME content. The IVOMD and ME contents calculated for the M30 and M40 Moringa samples were within the range previously reported (Melesse et al., 2013; Sultana et al., 2014), and higher that those reported for the other indigenous multipurpose trees (Anele et al., 2009).

Because of the high similarities in DM degradation patterns among the three different maturity cuts, the intermediate cut (M40) was used to represent Moringa when comparing with alfalfa hay in the $\mathrm{CP}$ degradation kinetics. No difference in protein solubility (a) between the two forage species was detected. However, the small differences observed for DM solubility (a) disappeared in the CP study, suggesting that the differences might not be due to the losing of DM particles from the bag but possibly the DM, as a whole, had higher degradability than the $\mathrm{CP}$ component. Following the same trend as for DM degradation kinetics, the insoluble but potentially degradable protein fraction (b) for $\mathrm{CP}$ was higher in Moringa foliage than alfalfa $(\mathrm{P}=0.05)$ which was reflected in a higher effective degradability (ED) that tended to be significant $(\mathrm{P}=0.07)$ at a lower passage rate $(k=0.02)$, although differences in effective degradability of CP disappeared with an increased transit rate $(\mathrm{k}=0.05)$. Fermentation of Moringa CP occurred at the same rate (c) as alfalfa, but the former showed a higher degradation potential (b) which would be derived from a simpler tertiary protein structure that allowed a higher degradation in the rumen environment along the retention time of forage particles. Putting the above together, it suggests that in producing animals, such as pregnant and lactating cows with $\mathrm{k}=0.05$, the amount of undegraded rumen protein (UDP) which can derived from Moringa foliage is similar to that from alfalfa (JahaniAzizabadi et al., 2009).

\section{CONCLUSION}

Moringa foliages harvested between 30 to 50 days after pruning had similar $\mathrm{CP}$ but lower fiber and higher non-fiber carbohydrate components as compared to alfalfa. There was no major difference in microbial fermentation rate among the different maturities of Moringa forages were observed. The results of in vitro fermentation and in situ degradation variables suggest the high similarities in kinetics of gas production and DM degradation patterns among the 3 different harvesting ages of Moringa, and nutritionally, the Moringa foliages are comparable to alfalfa.

\section{CONFLICT OF INTEREST}

There is no conflict of interest with any financial organization or individual on the material presented in this manuscript.

\section{ACKNOWLEDGEMENT}

This research did not receive any specific grant from funding agencies in the public, commercial, or notfor-profit sectors. Ahmad Reza Seradj was a recipient of a research training grant from the Government of Catalonia (FIDGR 2011-Generalitat de Catalunya) and Henris Morazán was supported by a grant from the Ministry of Foreign Affairs and Cooperation of Spain (MAEC-AECID 2009-2011). The authors wish to thank Leonidas Morazán for his assistance.

\section{REFERENCES}

Adeleke, O., O. Q. Adiamo, O. S. Fawale, \& G. Olamiti. 2017. Effect of soaking and boiling on anti-nutritional factors, oligosaccharide contents and protein digestibility of newly developed bambara groundnut cultivars. Turkish JAF. Sci.Tech. 5:1006-1014. https://doi.org/10.24925/turjaf. v5i9.1006-1014.949

Anele, U. Y., O. M. Arigbede, K. H. Südekum, A. O. Oni, A. O. Jolaosho, J. A. Olanite, A. I. Adeosun, P. A. Dele, K. A. Ike, \& O. B. Akinola. 2009. Seasonal chemical composition, in vitro fermentation and in sacco dry matter degradation of four indigenous multipurpose tree species in Nigeria. Anim. Feed Sci. Technol. 154:47-57. https://doi. org/10.1016/j.anifeedsci.2009.07.007

AOAC. 2010. Official Methods of Analysis. 18th ed. Assoc. Off. Anal.Chem., Arlington, VA.

Astuti, D. A., A. S. Baba, \& I. W. Wibawan. 2012. Rumen fermentation, blood metabolites, and performance of sheep fed tropical browse plants. Med. Pet. 34:201-206. https:// doi.org/10.5398/medpet.2011.34.3.201

Dey, A., S. S. Paul, P. Pandey, \& R. Rathore. 2014. Potential of 
Moringa oleifera leaves in modulating in vitro methanogenesis and fermentation of wheat straw in buffalo. Indian J. Anim. Sci. 84:533-538.

Fitri, A., T. Toharmat, D. A. Astuti, \& H. Tamura. 2015. The potential use of secondary metabolites in Moringa oleifera as an antioxidant source. Med. Pet. 38:169-175. https://doi. org/10.5398/medpet.2015.38.3.169

Gupta, K., G. K. Barat, D. S. Wagle, \& H. K. L. Chawla. 1989. Nutrient contents and antinutritional factors in conventional and non-conventional leafy vegetables. Food Chem. 31:105-116. https://doi.org/10.1016/0308-8146(89)90021-6

Jahani-Azizabadi, H., M. D. Mesgaran, R. Valizadeh, \& H. N. Moghaddam. 2009. Comparison of in vivo with in situ mobile bag and three step enzymatic procedures to evaluate protein disappearance of alfalfa hay and barley grain. Iran. J. Vet. Res. 10:260-266.

Kulivand, M. \& F. Kafilzadeh. 2015. Correlation between chemical composition, kinetics of fermentation and methane production of eight pasture grasses. Acta Sci. Anim. Sci. 37:9-14. https://doi.org/10.4025/actascianimsci.v37i1.24336

Melesse, A., H. Steingass, J. Boguhn, \& M. Rodehutscord. 2013. In vitro fermentation characteristics and effective utilisable crude protein in leaves and green pods of Moringa stenopetala and Moringa oleifera cultivated at low and mid-altitudes. J. Anim. Physiol. Anim. Nutr. 97:537-546. https://doi.org/10.1111/j.1439-0396.2012.01294.x

Müller, C. E. 2011. Equine ingestion of haylage harvested at different plant maturity stages. Appl. Anim. Behav. Sci. 134:144-151.https://doi.org/10.1016/j.applanim.2011.08.005

Odee, D. 1998. Forest biotechnology research in drylands of Kenya: The development of Moringa species. Dryland Biodiversity 2:7-8.

Ørskov, E. R. \& I. McDonald. 1979. The estimation of protein degradability in the rumen from incubation measurements weighted according to rate of passage. J. Agric. Sci. 92:499503. https://doi.org/10.1017/S0021859600063048

Pashaei, S., V. Razmazar, \& R. Mirshekar. 2010. Gas production: a proposed in vitro method to estimate the extent of digestion of a feedstuff in the rumen. J. Biol. Sci. 10:573580. https://doi.org/10.3923/jbs.2010.573.580

Sánchez, N. R., E. Spörndly, \& I. Ledin. 2006. Effect of feeding different levels of foliage of Moringa oleifera to creole dairy cows on intake, digestibility, milk production and composition. Livest. Sci. 101:24-31. https://doi.org/10.1016/j. livprodsci.2005.09.010

Seradj, A. R., L. Abecia, J. Crespo, D. Villalba, M. Fondevila, \& J. Balcells. 2014. The effect of Bioflavex ${ }^{\circledR}$ and its pure flavonoid components on in vitro fermentation parameters and methane production in rumen fluid from steers given high concentrate diets. Anim. Feed Sci. Technol. 197:85-91. https://doi.org/10.1016/j.anifeedsci.2014.08.013

Seradj, A. R., J. Balcells, H. Morazan, J. Alvarez-Rodriguez, D. Babot, \& G. De la Fuente. 2018a. The impact of reducing dietary crude protein and increasing total dietary fiber on hindgut fermentation, the methanogen community and gas emission in growing pigs. Anim. Feed Sci. Technol. 245:54-66. https://doi.org/10.1016/j.anifeedsci.2018.09.005

Seradj, A. R., A. Gimeno, M. Fondevila, J. Crespo, R. Armengol, \& J. Balcells. 2018b. Effects of the citrus flavonoid extract Bioflavex or its pure components on rumen fermentation of intensively reared beef steers. Anim. Prod. Sci. 58:553560. https://doi.org/10.1071/AN15146

Sultana, N., A. R. Alimon, K. S. Haque, A. Q. Sazili, H. Yaakub, \& S. M. J. Hossain. 2014. The effect of cutting interval on yield and nutrient composition of different plant fractions of Moringa oleifera tree. J. Food Agric. Environ. 12:599-604.

Tjørve, K. M. C., \& E. Tjørve. 2017. The use of Gompertz models in growth analyses, and new Gompertz-model approach: An addition to the Unified-Richards family. PLOS ONE. 12:e0178691. https://doi.org/10.1371/journal.pone.0178691

Ülger, I., M. Kaliber, T. Aya_an, \& O. Küçük. 2018. Chemical composition, organic matter digestibility and energy content of apple pomace silage and its combination with corn plant, sugar beet pulp and pumpkin pulp. S. Afr. J. Anim. Sci. 48:497-503. https://doi.org/10.4314/sajas.v48i3.10 